\title{
Increased peak expiratory flow variation in asthma: severe persistent increase but not nocturnal worsening of airway inflammation
}

\author{
N.H.T. ten Hacken*, W. Timens**, M. Smith**, G. Drok**, J. Kraan*, D.S. Postma*
}

Increased peak expiratory flow variation in asthma: severe persistent increase but not nocturnal worsening of airway inflammation. N.H.T. ten Hacken, W. Timens, M. Smith, G. Drok, J. Kraan, D.S. Postma. OERS Journals Ltd 1998.

ABSTRACT: Asthma at night is characterized by a nocturnal increase in airway obstruction. It has been hypothesized that nocturnal asthma results from an increase in airway wall inflammation at night. However, studies on inflammatory cells in bronchoalveolar lavage (BAL) fluid and bronchial biopsies have produced conflicting data.

This study assessed inflammatory cell numbers at 16:00 $\mathrm{h}$ and 04:00 $\mathrm{h}$ in bronchial biopsies of 13 healthy controls, 15 asthmatic patients with peak expiratory flow (PEF) variation $ð 15 \%$ and 10 asthmatic patients with $P E F$ variation $>15 \%$.

There was no significant increase at night in the number of CD3, CD4, CD8, CD25, AA1 (tryptase) and EG2-immunopositive cells in the submucosa in both groups. Numbers of EG2-positive cells in the two asthmatic groups were significantly higher than in healthy controls, both at 16:00 $\mathrm{h}(\mathrm{p}<0.05)$ and $04: 00 \mathrm{~h}(\mathrm{p}<0.01)$. The number of EG2, CD4 and CD25-positive cells at 04:00 and 16:00 $\mathrm{h}$ tended to be higher in asthmatics with a PEF variation $>15 \%$ than in asthmatics with PEF variation $015 \%$. At 04:00 $\mathrm{h}$ the median numbers of EG2-positive cells (per $\mathrm{mm}$ basement membrane) in subjects with PEF variation $>15 \%$ and $\varnothing 15 \%$ were 6 and 3 cells, respectively, and at 16:00 $\mathrm{h} 4$ and 2.5 cells respectively.

Increased nocturnal airway obstruction is not associated with increased numbers of inflammatory cells in the bronchial submucosa at night. Apparently, asthmatic patients with a peak expiratory flow variation $>15 \%$ suffer from a higher overall severity of bronchial inflammation at night and during the day.

Eur Respir J 1998; 12: 546-550.

Awakening at night due to asthma symptoms is very common: over $80 \%$ of subjects with asthma experience cough, wheeze and breathlessness at night [1]. Asthmatic subjects with nocturnal symptoms have a larger circadian variation in airway diameter than asthmatic subjects without nocturnal symptoms $[2,3]$. The term nocturnal asthma is often used in these patients and this suggests a distinct disease entity. Until now, no convincing evidence has been presented that nocturnal asthma has a unique pathogenesis $[4,5]$. One hypothesis is that increased airway obstruction at night is caused by increased airway inflammation in this period $[5,6]$. Indeed, asthmatic patients with increased nocturnal airway obstruction are more hyperresponsive for adenosine-5-monophosphate (AMP) at night than during the day, in contrast to asthmatic patients without increased nocturnal airway obstruction [7]. Studies on bronchoalveolar lavage (BAL) fluid in patients with nocturnal asthma have produced conflicting results: MARTIN et al. [8] and MACKAY et al. [9] found higher numbers of eosinophils at night than at day, whereas JARJOUR et al. [10] and OOSTERHOFF et al. [11, 12] found no differences. Further, two biopsy studies in patients with nocturnal asthma showed the same number of inflammatory cells in the central airways in the daytime and night-time [9, 13], but a higher number of
Depts of *Pulmonology and **Pathology, University Hospital Groningen, The Netherlands.

Correspondence: N.H.T. ten Hacken Dept of Pulmonology

University Hospital Groningen

P.O. Box 30.001

9700 RB Groningen

The Netherlands

Fax: 31503619320

Keywords: Airway inflammation biopsy

nocturnal asthma

Received: October 271997

Accepted after revision December 91997

This study was supported by a grant from the Netherlands Asthma Foundation (grant no. 92.28). eosinophils in the alveolar tissue at night than during the day [13].

In the present study bronchial biopsies were obtained at 16:00 $\mathrm{h}$ and 04:00 $\mathrm{h}$ from healthy controls, asthmatic patients with variation in peak expiratory flow (PEF) $ð 15 \%$ and asthmatic patients with PEF variation $>15 \%$. If increased nocturnal airway obstruction is caused by nocturnal worsening of airway inflammation, one would expect more inflammatory cells at 04:00 $\mathrm{h}$ than at 16:00 h, especially in asthmatics with PEF variation $>15 \%$. Alternatively, if increased nocturnal airway obstruction is only an expression of more severe asthma, one would expect more inflammatory cells both at 04:00 $\mathrm{h}$ and 16:00 $\mathrm{h}$ in the asthmatics with PEF variation $>15 \%$, than in the asthmatics with a PEF variation $ð 15 \%$.

\section{Materials and methods}

\section{Study design: time schedule}

To study day-night changes in inflammatory cells a bronchoscopy was performed, in a randomized order, at 16:00 $\mathrm{h}$ and at 04:00 h, with an interval of 7-14 days. Four 
weeks before the first bronchoscopy inhaled corticosteroids were stopped. Two weeks before the first bronchoscopy subjects were characterized by peripheral blood eosinophils, serum total immunoglobulin (Ig)E, reversibility of forced expiratory volume in one second (FEV1) after inhaling $400 \mu \mathrm{g}$ salbutamol, provocative concentration of methacholine or AMP causing a $20 \%$ fall in FEV1 (PC20). Three days before the first bronchoscopy, bronchodilators were withheld and PEF values were recorded at 08:00, 12:00, 16:00, 20:00, 24:00 and 04:00 h. PEF variation was defined as: (highest - lowest value)/mean of six measurements daily. Mean PEF variation was calculated as the average of the PEF variation measured during 3 days. Asthmatic subjects were divided on the basis of a mean PEF variation $\mathrm{d} 15 \%$ or $>15 \%$.

\section{Subjects}

Subjects aged 18-45 yrs were recruited in the authors outpatient clinic or by advertisements in local newspapers. Asthmatic subjects were selected on: a history consistent with asthma; presence of atopy (positive intracutaneous tests against house dust mite or two other aeroallergens),

Table 1. - Characteristics of participating subjects

\begin{tabular}{|c|c|c|c|c|c|c|c|c|c|c|}
\hline $\begin{array}{l}\text { Age } \\
\text { yrs }\end{array}$ & $\begin{array}{l}\text { Sex } \\
\mathrm{M} / \mathrm{F}\end{array}$ & $\begin{array}{l}\text { ICS } \\
\mu \mathrm{g} \cdot \mathrm{d}^{-1}\end{array}$ & $\begin{array}{l}\text { Total } \\
\text { IgE } \\
\text { IU.L-1 }\end{array}$ & $\begin{array}{l}\text { Eosinophils } \\
\quad \times 10^{9} \cdot \mathrm{L}^{-1}\end{array}$ & $\begin{array}{l}\text { FEV1 } \\
\% \text { pred }\end{array}$ & $\begin{array}{c}\mathrm{PC}_{20} \\
\text { Methacholine } \\
\mathrm{mg} \cdot \mathrm{mL}^{-1}\end{array}$ & $\begin{array}{c}\mathrm{PC} 20 \\
\mathrm{AMP} \\
\mathrm{mg} \cdot \mathrm{mL}^{-1}\end{array}$ & Awakening & $\begin{array}{c}\text { 16:00-04:00 h } \\
\text { FEV } 1 \\
\% \text { pred }\end{array}$ & $\begin{array}{c}\mathrm{PEF} \\
\text { variation } \\
\%\end{array}$ \\
\hline \multicolumn{11}{|c|}{ Healthy controls } \\
\hline 21 & $\mathrm{~F}$ & 0 & 944 & 0.11 & 122 & $>9.8$ & $>80$ & 1 & 0 & 3.0 \\
\hline 45 & $\mathrm{~F}$ & 0 & 7 & 0.04 & 121 & $>9.8$ & $>80$ & 1 & -1.1 & 4.4 \\
\hline 38 & $\mathrm{~F}$ & 0 & 2 & 0.03 & 119 & $>9.8$ & $>80$ & 1 & 1.3 & 5.0 \\
\hline 38 & M & 0 & 308 & 0.2 & 111 & $>9.8$ & $>80$ & 1 & 4.3 & 5.1 \\
\hline 25 & $\mathrm{~F}$ & 0 & - & 0.04 & 111 & $>9.8$ & $>80$ & 1 & -1.5 & 5.2 \\
\hline 35 & M & 0 & - & 0.04 & 86 & $>9.8$ & $>80$ & 1 & -0.7 & 6.0 \\
\hline 42 & $\mathrm{~F}$ & 0 & 26 & 0.05 & 117 & $>9.8$ & $>80$ & 1 & 0.6 & 6.7 \\
\hline 25 & $\mathrm{~F}$ & 0 & 4 & 0.12 & 85 & $>9.8$ & $>80$ & 1 & 2.1 & 8.0 \\
\hline 27 & $\mathrm{~F}$ & 0 & 9 & 0.14 & 104 & $>9.8$ & $>80$ & 1 & 7.4 & 8.9 \\
\hline 29 & M & 0 & 45 & 0.31 & 93 & $>9.8$ & $>80$ & 1 & 6.8 & 9.5 \\
\hline 26 & $\mathrm{~F}$ & 0 & 61 & 0.19 & 87 & $>9.8$ & $>80$ & 1 & -3.6 & 11.2 \\
\hline 42 & M & 0 & 71 & 0.05 & 108 & $>9.8$ & $>80$ & 1 & 7.0 & 11.5 \\
\hline 20 & M & 0 & - & 0.11 & 111 & $>9.8$ & $>80$ & 1 & 2.0 & 13.4 \\
\hline 29 & $5 \mathrm{M} / 8 \mathrm{~F}$ & 0 & 35.5 & 0.11 & 111 & $>9.8$ & $>80$ & - & 1.3 & 6.7 \\
\hline \multicolumn{11}{|c|}{ Asthmatics with PEF variation $ð 15 \%$} \\
\hline 26 & M & 400 & 1462 & 0.46 & 107 & 6.61 & 6.54 & 2 & 11.2 & 4.9 \\
\hline 37 & M & 0 & 78 & 0.17 & 96 & 0.24 & 2.57 & 1 & 4.5 & 5.2 \\
\hline 22 & $\mathrm{M}$ & 0 & 434 & 0.27 & 92 & 3.85 & 5.0 & 1 & -1.0 & 5.6 \\
\hline 25 & $\mathrm{~F}$ & 1600 & $>2000$ & 0.29 & 92 & 1.25 & 19 & 1 & 0.0 & 6.0 \\
\hline 40 & $\mathrm{~F}$ & 1200 & 249 & 0.31 & 110 & 0.61 & 8.82 & 1 & 4.2 & 6.4 \\
\hline 31 & $\mathrm{~F}$ & 800 & 358 & 0.44 & 103 & 2.78 & 22 & 1 & 14.8 & 6.9 \\
\hline 20 & $\mathrm{~F}$ & 0 & 1190 & 0.36 & 96 & 3.12 & 6.82 & 1 & 3.0 & 7.1 \\
\hline 26 & M & 800 & 782 & 0.41 & 97 & 0.52 & 8.04 & 1 & 7.8 & 9.9 \\
\hline 43 & M & 1000 & - & 0.26 & 83 & 1.09 & 1.10 & 4 & 4.8 & 10.7 \\
\hline 19 & M & 0 & 420 & 0.54 & 78 & 0.19 & 0.65 & 1 & 19.3 & 11.4 \\
\hline 44 & M & 200 & 49 & 0.15 & 98 & 0.35 & 2.03 & 2 & 17.3 & 11.8 \\
\hline 21 & $\mathrm{~F}$ & 400 & 898 & 0.16 & 102 & 0.20 & 1.95 & 1 & 3.9 & 12.6 \\
\hline 29 & M & 0 & 70 & 0.12 & 101 & 2.03 & 22.8 & 1 & 2.0 & 12.9 \\
\hline 20 & $\mathrm{M}$ & 0 & 175 & 0.15 & 83 & 0.42 & 5.43 & 1 & 12.7 & 13.9 \\
\hline 19 & $\mathrm{M}$ & 0 & 257 & 0.36 & 87 & 0.15 & 1.38 & 2 & 14.2 & 14.1 \\
\hline 26 & $10 \mathrm{M} / 5 \mathrm{~F}$ & 200 & 389 & 0.29 & 96 & 0.61 & 5.43 & & 4.8 & 9.9 \\
\hline \multicolumn{11}{|c|}{ Asthmatics with PEF variation $>15 \%$} \\
\hline 25 & F & 0 & 95 & 0.08 & 106 & 0.15 & 2.37 & 4 & 2.3 & 16.4 \\
\hline 42 & $\mathrm{~F}$ & 1200 & 442 & 0.13 & 85 & 0.08 & 1.50 & 4 & -5.7 & 17.4 \\
\hline 32 & M & 800 & 274 & 0.21 & 67 & 0.13 & 1.15 & 1 & 7.3 & 19.9 \\
\hline 26 & $\mathrm{~F}$ & 0 & 299 & 0.19 & 91 & 0.74 & 4.77 & 1 & 7.6 & 21.2 \\
\hline 44 & M & 200 & 50 & 0.47 & 97 & 0.14 & 0.65 & 3 & 8.3 & 21.2 \\
\hline 45 & $\mathrm{~F}$ & 0 & 354 & 0.13 & 106 & 4.04 & 12 & 1 & -0.8 & 23.4 \\
\hline 36 & M & 800 & 300 & 0.34 & 65 & 0.25 & 0.54 & 1 & 29.4 & 24.1 \\
\hline 35 & $\mathrm{M}$ & 1200 & 130 & 0.5 & 79 & 0.28 & 0.18 & 1 & 8.0 & 24.9 \\
\hline 33 & $\mathrm{M}$ & 0 & - & 0.51 & 114 & 0.90 & 6.0 & 4 & 19.0 & 27.0 \\
\hline 43 & $\mathrm{~F}$ & 0 & 168 & 0.18 & 79 & 0.09 & 0.29 & 3 & 16.4 & 36.8 \\
\hline 35 & $5 \mathrm{M} / 5 \mathrm{~F}$ & 100 & 274 & 0.20 & 88 & $0.20 *$ & $1.33 *$ & & 7.8 & 22.3 \\
\hline
\end{tabular}

Group data are medians. M: male; F: female; ICS: inhaled corticosteroids; IgE: immunoglobulin E; FEV1: forced expiratory volume in one second; PC20: provocative concentration causing a 20\% fall in FEV1; PEF: peak expiratory flow. Awakening: 1: never or only during respiratory infections; 2: four times per month; 3: four times per week; 4: almost every night. *: p<0.05 compared to asthmatics with PEF variation $ð 15 \%$. 
FEV $1>1.5 \mathrm{~L}$ and $>60 \%$ predicted, $\mathrm{PC} 20$ methacholine bromide $ð 9.8 \mathrm{mg} \cdot \mathrm{mL}^{-1}, \mathrm{PC} 20$ AMP $ð 80 \mathrm{mg} \cdot \mathrm{mL}^{-1}$ and no use of oral corticosteroids within 2 months or inhaled corticosteroids within 1 month before the study. Healthy volunteers were selected on: no history of lung disease, FEV1 $>1.5 \mathrm{~L}$ and $>85 \%$ pred, no atopy and no airway hyperresponsiveness for methacholine or AMP. Subjects who had smoked during the past 2 yrs or had a respiratory infection during the past 4 weeks were excluded. Thirteen healthy volunteers and 25 asthmatic subjects participated in this study (table 1). All subjects gave written informed consent. This investigation was approved by the medical ethics committee of the University Hospital.

\section{Bronchoscopy and processing of the biopsies}

After determination of FEV1, bronchoscopy was performed using an Olympus B1 IT10 flexible fibreoptic bronchoscope (Olympus Optical, Tokyo, Japan), according to the guidelines of the American Thoracic Society (ATS) [14]. Biopsies were taken from the subcarinae of the left or right lower lobe using a fenestrated forceps (FB-21C, Olympus, Tokyo, Japan). Biopsies were mounted in Tissue Tek (Sakura, Tokyo, Japan) and snap-frozen by immersing in isopentane $\left(-80^{\circ} \mathrm{C}\right)$. Frozen sections of $4 \mu \mathrm{m}$ thickness were immunostained for CD3, CD4, CD25 (Becton-Dickinson, San Jose, CA, USA), CD8 (own laboratory), EG2 (Sanbio, Uden, The Netherlands) and AA1 (Dako, ITK, Denmark). An immunoperoxidase streptavidin-biotin method was used with haematoxylin as the counterstain. In order to evaluate the bronchial biopsy architecture, sections were stained with Mayer's haematoxylin and eosin. The observer was blind to subject characteristics and time points of biopsy collection, by coding of all sections. Counting was carried out using a light microscope at a magnification of $400 \times$. Positive cells were counted at random, from representative sections at a depth of $100 \mu \mathrm{m}$ below an intact basement membrane (BM) with a cumulative length of $1000 \mu \mathrm{m}$, using an eyepiece graticule (cross-points each $25 \mu \mathrm{m}$ at $400 \times)$. A representative part of the biopsy was chosen for evaluation on basis of: 1) integrity of bronchial tissue, 2) thickness of the submucosa Š $100 \mu \mathrm{m}$, and 3) absence of smooth muscle or mucous glands. Counting was started at those locations that most closely met the above-mentioned criteria. Counting was performed twice by the same ob- server; the mean cell numbers were calculated and expressed as the number of positive cells. $\mathrm{mm}^{-1} \mathrm{BM}\left(0.1 \mathrm{~mm}^{2}\right.$ tissue). Intra-observer reproducibility of counts of CD3, CD4, CD8, CD25, EG2 and AA1-immunopositive cells sections revealed a mean difference (confidence interval) of $10.4(3.4,17.4),-0.8(-2.5,0.9),-2.2(-6.3,1.9),-0.05$ $(-0.15,0.05),-1.2(-2.0,-0.35)$ and $2.9(1.3,4.5)$ cells, respectively. Intra-observer correlation of counts of $\mathrm{CD} 3$, CD4, CD8, CD25, EG2 and AA1-immunopositive cells were: $0.88,0.99,0.82,0.99,0.93$ and 0.84 , respectively $(\mathrm{p}<0.001)$.

\section{Data analysis}

All analyses were performed with the SPSS/PC 6.01 software package (SPSS, Chicago, IL, USA). Values of $\mathrm{p}<0.05$ were considered statistically significant. The Student's t-test was used to compare clinical variables between groups, on condition of a normal distribution. The Mann-Whitney U-test was used to compare cell numbers between groups, and Wilcoxon's matched sign rank test was used to compare (paired) cell numbers at 16:00 $\mathrm{h}$ and 04:00 h within a group. Correlations between cell numbers and between cell numbers and clinical variables were made using Spearman's rank correlation tests. Reproducibility of cell counts was tested using the principles of B Land and Altman [15].

\section{Results}

\section{Clinical characteristics}

The 20 male and 18 female subjects were equally distributed between the three groups $(\mathrm{p}=0.19)$. No significant differences were present in markers for atopy (eosinophilia, total IgE) and airway obstruction (FEV1 \% pred, reversibility) between the asthmatic patients with PEF variation ð15\% or $>15 \%$ (table 1). Asthmatic patients with a PEF variation $>15 \%$ showed lower PC20 values for AMP ( $<<$ $0.05)$ and methacholine $(\mathrm{p}<0.05)$ than those with PEF variation $ð 15 \%$. Nocturnal awakening at least four times a week was present in one patient (out of 15) with PEF variation $ð 15 \%$ versus five patients (out of 10) with PEF variation $>15 \%$ (chi-square: $\mathrm{p}<0.05)$.

Table 2. - Inflammatory cells at 16:00 $\mathrm{h}$ and 04:00 $\mathrm{h}$

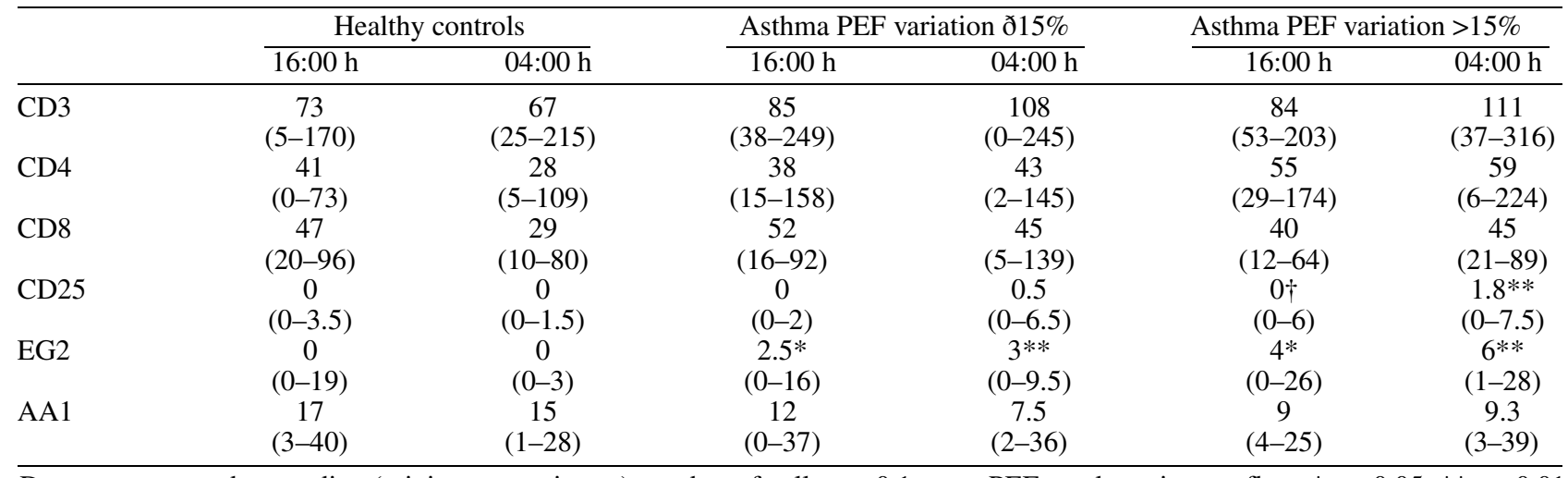

Data are presented as median (minimum-maximum) number of cells per $0.1 \mathrm{~mm}^{2}$. PEF: peak expiratory flow. $*$ : $\mathrm{p}<0.05, * *: \mathrm{p}<0.01$ versus controls; $\uparrow$ : $\mathrm{p}=0.08$ versus $04: 00 \mathrm{~h}$ within the group. 


\section{Differences in cell numbers in bronchial biopsies}

16:00 $h$ versus 04:00 $h$ (within groups). The number of CD3, CD4, CD8, CD25, EG2 and AA1-positive cells at 04:00 $\mathrm{h}$ was not significantly higher than at 16:00 $\mathrm{h}$ in the asthmatics with PEF variation $>15 \%$, the asthmatics with PEF variation $ð 15 \%$, or the healthy controls (table 2 ). The number of CD25-positive cells at 04:00 h tended $(\mathrm{p}=0.08)$ to be higher than at 16:00 $\mathrm{h}$ in the asthmatics with a PEF variation $>15 \%$.

16:00 versus 16:00 $h$ and 04:00 $h$ versus 04:00 $h$ (between groups). The number of EG2-positive cells in the asthmatics with a PEF variation $ð 15 \%$ and $>15 \%$ was significantly higher than in healthy controls, both at 16:00 $\mathrm{h}$ and 04:00 h. The number of CD25-positive cells at 04:00 $\mathrm{h}$ in the asthmatics with a PEF variation $>15 \%$ was higher than in healthy controls. Inflammatory cell numbers did not significantly differ between the asthmatic patients with PEF variation $ð 15 \%$ and $>15 \%$.

Relationship between clinical variables and inflammatory cells. The number of inflammatory cells in biopsies of all asthmatic patients was not correlated with important clinical variables such as FEV1 \% pred, PC20 methacholine, PC20 AMP and mean PEF variation. The 16:00-04:00 h difference in CD25-positive cells was not significantly correlated with the 16:00-04:00 h FEV1 or PEF variation. The numbers of CD25-positive cells at 16:00 $\mathrm{h}$ and 04:00 $\mathrm{h}$ were correlated with peripheral blood eosinophilia at 16:00 $\mathrm{h}(\mathrm{r}=0.48, \mathrm{p}=0.017)$ and at 04:00 h $(\mathrm{r}=0.43, \mathrm{p}=0.034)$, respectively.

\section{Discussion}

This study demonstrated in the first place that the number of inflammatory cells in the bronchial wall of asthmatic patients at night is not higher than during the day. Only CD25-positive cells tended $(p=0.08)$ to be higher at night in asthmatics with a PEF variation $>15 \%$. However, the airway wall tissue of most asthmatics, and also of those with a PEF variation $>15 \%$, contained very low numbers of CD25-positive cells. Therefore, a nocturnal increase in these cells is not expected to play an important role in increasing airway obstruction at night. This study further showed that EG2, CD4 and CD25-positive cells at 04:00 and at 16:00 $\mathrm{h}$ tended to be higher in asthmatics with a PEF variation $>15 \%$ than in asthmatics with a PEF variation $\partial 15 \%$. Together, these results suggest that patients with larger circadian variations in airway diameter are probably patients with a higher overall severity of bronchial inflammation. The increase in nocturnal airway obstruction does not seem to be the result of an increasing number of inflammatory cells in the bronchial submucosa at night.

Our results are in line with two other biopsy studies on bronchial inflammation in nocturnal asthma, despite the methodological differences of these studies (table 3). MACKAY et al. [9], for example, did not find day-night differences in the number of lymphocyte subsets and eosinophils in biopsies of subjects with nocturnal asthma. However, their patients were treated with inhaled corticosteroids and theophyllines, both of which can theoretically suppress nocturnal increases in inflammation. Moreover, their study lacked a control group of patients with non-nocturnal asthma. KRAFT et al. [13] excluded patients with corticosteroid therapy, whereas theophyllines were permitted. As in the present study they did not find day-night differences in inflammatory cells in biopsies from the central airways. If any conclusion was to be drawn, the number of eosinophils seemed to be higher during the day. In biopsies from the peripheral airways of patients with nocturnal asthma, they found more eosinophils at night than during the day. However, five out of 11 pairs of biopsies had to be ex-cluded because the biopsies were too small or the morphology of the tissue was poor [13]. The present study had the methodological advantage that patients with large PEF variations were compared with two control groups (healthy controls and asthmatic subjects with low PEF variations) and that subjects did not use anti-inflammatory medication. Consistent with the earlier studies it was demonstrated that inflammatory cells are not increased at night in the central airways.

There are several explanations for the apparent discrepancy between increased airway obstruction at night and the lack of an increased number of inflammatory cells at night in patients with nocturnal asthma. An increased cellular traffic from the vascular compartment to the airway

Table 3. - Comparison of three biopsy studies on nocturnal asthma

\begin{tabular}{|c|c|c|c|}
\hline & KRAFT et al. [13] & MACKAY et al. [9] & This study \\
\hline NA defined as & $\begin{array}{l}\text { Overnight fall in PEF }>15 \% \\
\text { during Š } 4 / 7 \text { days }\end{array}$ & $\begin{array}{l}\text { Overnight fall in PEF }>15 \% \\
\text { and awakening }>1 \text { per week }\end{array}$ & $\begin{array}{l}\text { Mean } \text { PEF variation }>15 \% \text { during } \\
3 \text { subsequent days }\end{array}$ \\
\hline Control groups & NNA & Healthy controls & NNA and healthy controls \\
\hline Anti-inflammatory medication & Theophyllines & Inhaled corticosteroids & - \\
\hline Location investigation & $\begin{array}{l}\text { Central airways and alveolar } \\
\text { tissue, right or left lower lobe }\end{array}$ & $\begin{array}{l}\text { Central airways, middle or } \\
\text { lingular lobe }\end{array}$ & $\begin{array}{l}\text { Central airways, right or left } \\
\text { lower lobe }\end{array}$ \\
\hline Processing of biopsies & Paraffin & Snap frozen (Tissue Tek) & Snap frozen (Tissue Tek) \\
\hline $\begin{array}{l}\text { Examination of inflammatory } \\
\text { cells }\end{array}$ & $\begin{array}{l}\text { LM + EM on morphological } \\
\text { criteria, eosinophils, } \\
\text { neutrophils, lymphocytes, } \\
\text { epithelial cells, macrophages }\end{array}$ & $\begin{array}{l}\text { LM on immunostaining: } \\
\text { CD } 4 \text {, CD8, CD } 45, \text { EG2- } \\
\text { positive cells }\end{array}$ & $\begin{array}{l}\text { LM on immunostaining: } \\
\text { CD3, CD4, CD8, CD25, EG2, } \\
\text { AA1-positive cells }\end{array}$ \\
\hline \multicolumn{4}{|l|}{ Findings: } \\
\hline $16: 00$ vs $04: 00 \mathrm{~h}$ in NA & Eosinophils at 16:00 $\mathrm{h} \uparrow(\mathrm{TBB})$ & No difference & No difference \\
\hline NA $v s$ NNA at $16: 00 \mathrm{~h}$ & No difference (TBB and BB) & - & No difference \\
\hline NA $v s$ NNA at $04: 00 \mathrm{~h}$ & Eosinophils in NA $\uparrow(\mathrm{TBB})$ & - & No difference \\
\hline
\end{tabular}

NA: nocturnal asthma; NNA: non-nocturnal asthma; PEF: peak expiratory flow; LM: light microscopy; EM: electron microscopy; TBB: transbronchial biopsies; BB: bronchial biopsies; $\uparrow$ : increase. 
lumen does not necessarily result in higher cell numbers in the bronchial submucosa at night. This hypothesis is supported by MACKAY et al. [9], who demonstrated higher levels of eosinophils and lymphocytes in BAL fluid at night, whereas numbers of eosinophils and lymphocyte subsets in bronchial biopsies did not change. In contrast, three other BAL fluid studies [10-12] did not find a nocturnal increase in inflammatory cells or their mediators. A second explanation may be that the increase in nocturnal inflammation takes place at other locations in the lung. By performing transbronchial biopsies, KRAFT et al. [13] showed a higher number of eosinophils at night in the alveolar tissue in patients with nocturnal asthma. This finding is in line with a study by the same authors on BAL fluid [8]. However, the contribution of these eosinophils to increased nocturnal airway obstruction remains uncertain. Two studies $[10,12]$ exploring the alveolar compartment with BAL fluid were not able to show higher levels of eosinophil-derived neurotoxin (EDN) at night. Another explanation may be that increased degranulation or cell lysis in the bronchial wall leads to increased airway inflammation at night without an increased number of inflammatory cells [16]. However, no studies are yet available comparing numbers of eosinophils with levels of free eosinophil cationic protein (ECP), EDN or major basic protein (MBP) in the submucosa. Further, it cannot be excluded that another group of (activated) cells or mediators not investigated in this study is important for nocturnal asthma.

It could be argued that the method of separating nocturnal from non-nocturnal asthmatics was not successful, thereby obscuring a real effect of increased inflammation at night. In a similarly designed study in our hospital [7] a PEF variation $ð 15 \%$ or $>15 \%$ was found to separate clearly the patients with symptoms of asthma at night, accompanied by an increase in airway obstruction, assessed with FEV1. In the present study, this cut-off point was less successful, as evidenced by a similar nocturnal decrease in FEV1 \% pred in both groups (table 1). One explanation may be that the PEF variation was measured at home, while patients slept in the hospital before the 04:00 h bronchoscopy. Patients are probably less exposed to house dust in the hospital than at home. Also, the stress of being in a hospital and the anticipation of a nocturnal bronchoscopy may have resulted in altered sleep patterns. The variation in PEF was assessed by subtracting the lowest from the highest value of six measurements (in 3 following days). Theoretically, the highest PEF value does not necessarily occur around 16:00 h; neither does the lowest PEF value have to occur around 04:00 h. Other (noncircadian) acute factors may influence PEF measurements, such as exposure to smoke or an allergen at an alternative time point. Because of the above considerations the patients were divided retrospectively on the basis of 16:00-04:00 h FEV1 $\%$ pred $ð 10 \%(n=16)$ or $>10 \%(n=9)$. This did not change the results. Thus, separating asthmatic patients on the basis of an actual decline in lung function at night does not lead to other conclusions with respect to the presence and activation of inflammatory cells in the bronchial submucosa.

In conclusion, increased nocturnal airway obstruction in patients with large variations in peak expiratory flow is not associated with an increased nocturnal presence of inflammatory cells in the bronchial submucosa. Because nocturnal increases in inflammatory cells and mediators in bronchoalveolar lavage fluid are not uniformly reported in the literature it is difficult to draw definitive conclusions about the pathophysiology of nocturnal asthma. In the author's opinion, future research should focus on increases in cell traffic (from the vascular compartment, via the airway wall, to the airway lumen), cell activation and cell death at night.

Acknowledgements: The authors thank R. Douma, R. Meijer and S. Rutgers for their assistance during bronchoscopies at night.

\section{References}

1. Turner-Warwick M. Epidemiology of nocturnal asthma. Am J Med 1988; 85: 6-8.

2. Clark TJ. Diurnal rhythm of asthma. Chest 1987; 91: 137S-141S.

3. Hetzel MR, Clark TJ. Comparison of normal and asthmatic circadian rhythms in peak expiratory flow rate. Thorax 1980; 35: 732-738.

4. Weersink EJ, Postma DS. Nocturnal asthma: not a separate disease entity. Respir Med 1994; 88: 483-491.

5. Postma DS, Oosterhoff Y, van Aalderen WM, Kauffman HF, Wempe JB, Koëter GH. Inflammation in nocturnal asthma? Am J Respir Crit Care Med 1994; 150: S83-S86.

6. Oosterhoff Y, Timens W, Postma DS. The role of airway inflammation in the pathophysiology of nocturnal asthma. Clin Exp Allergy 1995; 25: 915-921.

7. Oosterhoff Y, Koëter GH, De Monchy JGR, Postma DS. Circadian variation in airway responsiveness to metacholine, and AMP in atopic asthmatic subjects. Am Rev Respir Dis 1993; 147: 512-517.

8. Martin RJ, Cicutto LC, Smith HR, Ballard RD, Szefler SJ. Airways inflammation in nocturnal asthma. Am Rev Respir Dis 1991; 143: 351-357.

9. Mackay TW, Wallace WAH, Howie SEM, et al. Role of inflammation in nocturnal asthma. Thorax 1994; 49: 257-262.

10. Jarjour NN, Busse WW, Calhoun WJ. Enhanced production of oxygen radicals in nocturnal asthma. Am Rev Respir Dis 1992; 146: 905-911.

11. Oosterhoff Y, Hoogsteden HC, Rutgers B, Kauffman HF, Postma DS. Lymphocyte and macrophage activation in bronchoalveolar lavage fluid in nocturnal asthma. Am $J$ Respir Crit Care Med 1995; 151: 75-81.

12. Oosterhoff Y, Kauffman HF, Rutgers B, Zijlstra FJ, Koëter GH, Postma DS. Inflammatory cell number and mediators in bronchoalveolar lavage fluid and peripheral blood in asthmatic subjects with increased nocturnal airways narrowing. J Allergy Clin Immunol 1995; 96 : 219-229.

13. Kraft M, Djukanovic R, Wilson S, Holgate ST, Martin RJ. Alveolar tissue inflammation in asthma. Am J Respir Crit Care Med 1996; 154: 1505-1510.

14. NHLBI Workshop summaries. Summary and recommendations of a workshop on the investigative use of fibreoptic bronchoscopy and bronchoalveolar lavage in asthmatics. Am Rev Respir Dis 1985; 132: 180-182.

15. Bland JM, Altman DG. Statistical methods for assessing agreement between two methods of clinical measurement. Lancet 1986; i: 307-310.

16. Persson CGA, Erjefalt JS. Eosinophil lysis and free granules: an in vivo paradigm for cell activation and drug development. Trends Pharmacol Sci 1997; 18: 117-123. 